\title{
Water vapour adsorption and desorption in GCLs
}

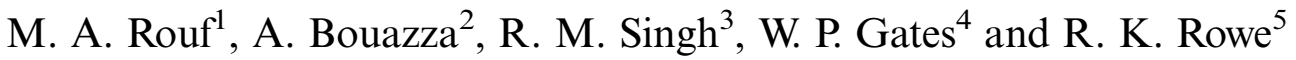 \\ ${ }^{1}$ PhD Student, Department of Civil Engineering, 18 Alliance Lane, Monash University, Victoria 3800, \\ Australia, Telephone: +613 99058901; Telefax: +613 99054944; E-mail: md.rouf@monash.edu \\ ${ }^{2}$ Professor, Department of Civil Engineering, 23 College Walk, Monash University, Victoria 3800 , \\ Australia, Telephone: +61 3 99054956; Telefax: +61 3 99054944; E-mail: malek.bouazza@monash.edu \\ (corresponding author) \\ ${ }^{3}$ Research Fellow, Department of Civil Engineering, 23 College Walk, Monash University, Vic. 3800, \\ Australia, Telephone: +61 3 99054981; Telefax: +613 99054944; E-mail: Rao.Singh@monash.edu \\ ${ }^{4}$ Senior Research Fellow, Department of Civil Engineering, 18 Alliance Lane, Monash University, Vic. \\ 3800, Australia, Telephone: +61 3 99054664; Telefax:+613 99054944; E-mail:will.gates@monash.edu \\ ${ }^{5}$ Professor and Canada Research Chair in Geotechnical and Geoenvironmental Engineering, \\ Department of Civil Engineering, Queen's University, Ellis Hall, Kingston Ontario, Canada K7L 3N6, \\ Telephone: +1 613 5333113; Telefax: +1 613 5332128; E-mail: kerry.rowe@queensu.ca
}

Received 5 April 2015, revised 29 June 2015, accepted 5 August 2015, published 5 October 2015

\begin{abstract}
Super-saturated salt solutions are used to control relative humidity $(\mathrm{RH})$ and to infer the hydration (water uptake and loss) behaviour of three needle-punched geosynthetic clay liners (GCLs) with respect to time under conditions of both free swell and $20 \mathrm{kPa}$ applied stress. It is shown that RH and applied stress play a key role in the hydration behaviour with time when GCL specimens were in equilibrium with water vapour. It was also observed that water uptake and loss was affected by the bentonite form (powdered or granular) and mineralogy of the bentonite. However, the effect of GCL structure (i.e. difference in geotextiles and bonding of needle-punched fibres to the carrier geotextile) on their hydration behaviour for GCLs with similar form of bentonite was not significant for $\mathrm{RH} \leq 97.7 \%$. The effect of GCL structure became more apparent at 100\% RH (for all GCLs). The results presented in this study can be used to better assess the hydration of GCLs in field applications such as waste containment liners and cover systems at different RH and overburden stress conditions.
\end{abstract}

KEYWORDS: Geosynthetics, Adsorption/desorption, Bentonite form, Geosynthetic clay liners, Relative humidity, Stress, Water vapour

REFERENCE: Rouf, M. A., Bouazza, A., Singh, R. M., Gates, W. P. and Rowe, R. K. (2016). Water vapour adsorption and desorption in GCLs. Geosynthetics International, 23, No. 2, 86-99. [http://dx.doi.org/10.1680/jgein.15.00034]

\section{INTRODUCTION}

Geosynthetic clay liners (GCLs) are often used in combination with a geomembrane to form composite liner systems in municipal solid waste containment facilities, heap leach pads and other mining/industrial containment facilities (Bouazza 2002; Rowe 2005, 2012, 2014; Hornsey et al. 2010; Bouazza et al. 2014). In these applications, GCLs need to be confined under a suitable normal stress and sufficiently hydrated prior to being in contact with leachates and other types of fluids such as gases to minimise potential advective/diffusive transport of contaminants (Vasko et al. 2001; Vangpaisal and Bouazza 2004; Lee and Shackelford 2005; Bouazza and Rahman 2007; Katsumi et al. 2008; Gates and Bouazza 2010; Abuel-Naga and Bouazza 2013; Bradshaw et al. 2013; Rouf et al. 2013, 2014a, 2014b; Bannour et al. 2014;
Bouazza and Gates 2014; Liu et al. 2014, 2015; Makusa et al. 2014; Chen et al. 2015; Puma et al. 2015).

The initial as-manufactured state of the bentonite within many GCLs when installed is typically a gravimetric moisture content of approximately 10\%. Generally, it is expected that hydration will begin from subsoil at the time of installation and should be complete prior to significant contact with leachate or gas. Rayhani et al. (2011), Chevrier et al. (2012) and Anderson et al. (2012) have indicated that the in-field hydration of a GCL is dependent on the subsoil particle size distribution and its initial water content. Thus, subsoil suction and/or relative humidity are known to control moisture movement between the GCL and the subsoil. Moisture migration between the GCL and the subsoil can occur through the movement of either liquid water or water vapour. A greater differential in relative humidity $(\mathrm{RH})$ or matric 
suction at the GCL-subsoil interface will result in faster and more complete final hydration of the GCL (Rayhani et al. 2011; Anderson et al. 2012; Chevrier et al. 2012). GCL hydration will continue generally through moisture migration from the subsoil to the GCL until equilibrium in the RH or matric potential is achieved. The GCL hydration process is summarised in Figure 1. It can occur through a process where liquid water movement takes place when there is intimate contact between GCL and subsoil, and when the subsoil is moist enough to wet the bentonite of the GCL (case 1), or in the case of a water-deficient subsoil (case 3) through an additional process where the uptake of water is in the form of water vapour. However, when contact between GCL and subsoil is poor, then water uptake in GCL will occur mostly through water vapour movement, as indicated in case 2 and case 4. Furthermore, it is evident from Kröhn (2005) that dry compacted bentonite absorbs water vapour even when the bentonite is in contact with liquid water at isothermal condition. Therefore, one can postulate that
GCL can absorb water vapour from the subsoil for all cases shown in Figure 1.

Moreover, the presence of daily or seasonal solar-driven thermal cycles on exposed composite liners (Rowe et al. $2011,2014)$ or exposure to heat produced in landfills or mining containment facilities of base or cover liners (Bouazza et al. 2011, 2013, 2014; Abuel-Naga and Bouazza 2013; Abuel-Naga et al. 2013; Rowe and Verge 2013) can have an impact on the GCL hydration process. In this case, GCLs can lose/desorb water as vapour as indicated for all cases shown in Figure 1, if the relative humidity in the vicinity of the GCL decreases (Rowe 2007; Chevrier et al. 2012). The hydration process (both water adsorption and desorption) of the GCL in a barrier system can be considered, in most cases, to be controlled by vapour transfer between the GCL and the subsoil. The amount of vapour transfer is dominated by the difference in RH at the interface between the GCL and the subsoil. $\mathrm{RH}$ is defined as the ratio of the vapour pressure of water in air $\left(P_{0}\right)$ at a particular temperature
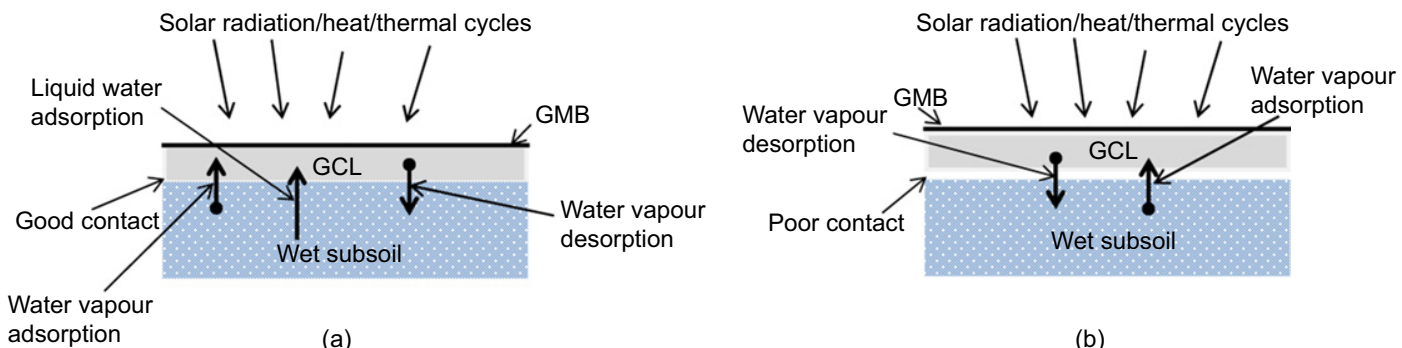

(b)
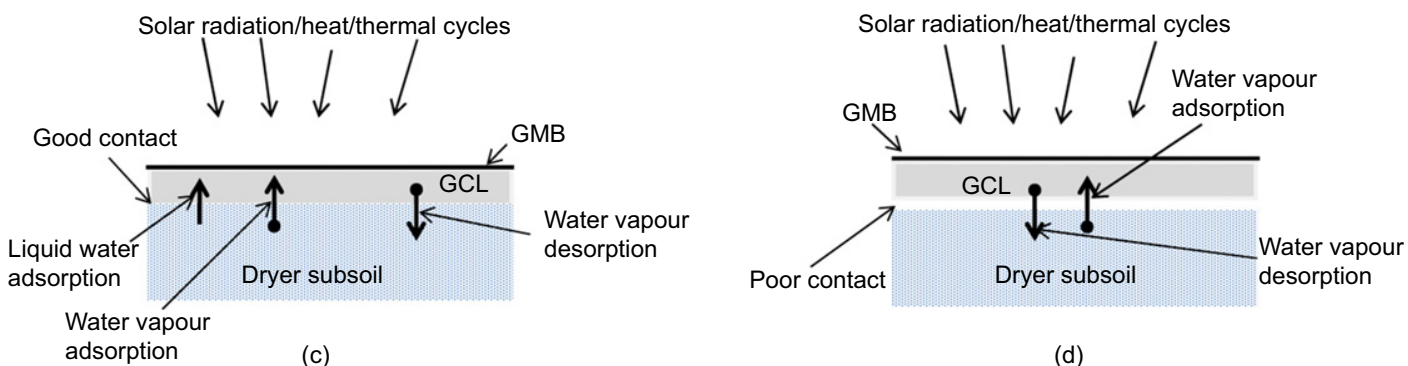

(d)

Figure 1. Water adsorption/desorption of GCL in geomembrane (GMB)/GCL composite: (a) case 1, (b) case 2, (c) case 3, (d) case 4

Table 1. Basic characteristics of geosynthetic clay liners used in this study

\begin{tabular}{|l|l|l|l|}
\hline Parameters & GCL-1 & GCL-2 & GCL-3 \\
\hline Bentonite type & Sodium/powder & Sodium/powder & Sodium/granular \\
Bonding & Needle-punched & Needle-punched & Needle-punched \\
Cover geotextile & NW & NW & NW \\
Carrier geotextile & W & NW+W & W \\
$M_{\text {GCL }}\left(\mathrm{kg} / \mathrm{m}^{2}\right)$ & $3.93-5.64$ & $3.93-5.50$ & $3.00-4.15$ \\
$M_{\text {bent }}\left(\mathrm{kg} / \mathrm{m}^{2}\right)$ & $3.48-5.19$ & $3.01-4.58$ & $2.60-3.75$ \\
$M_{\text {cover }}\left(\mathrm{kg} / \mathrm{m}^{2}\right)$ & 0.30 & 0.35 & 0.25 \\
$M_{\text {Carrier }}\left(\mathrm{kg}^{2}\right)$ & 0.15 & 0.57 & 0.15 \\
Thermally treated & Yes & Yes & No \\
a Average peel strength $(\mathrm{N} / \mathrm{m})$ & 381 & 673 & 588 \\
Initial GCL thickness $(\mathrm{mm})$ & $6.09-7.41$ & $7-03-8.91$ & $5.62-7.33$ \\
Initial moisture content $(\%)$ & $7-10$ & $9-13$ \\
\hline
\end{tabular}

$\mathrm{NW}$, nonwoven; $\mathrm{W}$, woven; $\mathrm{NW}+\mathrm{W}$, nonwoven with woven scrim reinforcement.

${ }^{a}$ Peel strength test was done by Geosynthetic Centre of Excellence, Geofabrics Australasia Pty. Ltd. 
to the equilibrium vapour pressure of water $\left(P_{\mathrm{e}}\right)$ at that temperature.

Vapour adsorption and desorption experiments have been conducted extensively on expansive clayey soils at different equilibrium RH values and it was observed that vapour water sorption isotherms increased with increases in RH (Mooney et al. 1952; Kraehenbuehl et al. 1987; Cases et al. 1997; Chiou and Rutherford 1997; Delage et al. 1998; Tang and Cui 2005, 2006; Likos and Lu 2006; Clausen et al. 2009; among many others). It was also documented from earlier work (Kraehenbuehl et al. 1987; Cases et al. 1997; Chiou and Rutherford 1997; Likos and $\mathrm{Lu} 2006$ ) that at $\mathrm{RH}<85-95 \%$, water sorption occurred both within the inter-layer spaces and on the external surface of the montmorillonites. This former hydration promotes crystalline swelling through the hydration of exchangeable cations of the dry clay. Furthermore, vapour equilibration time in sandstone and clayey soil specimens respectively, was investigated by Johannesson and Janz (2002) and Tang and Cui (2006) and reported that the factors such as sample size, material and technique used for controlling $\mathrm{RH}$ governed the equilibration time and that the final water content at equilibrium remained the same. However, to the authors' knowledge, only very limited research has been reported on the vapour water adsorption/desorption of GCLs so far, indicating a paucity of knowledge regarding this issue.

The objective of this study was to investigate the adsorption/desorption of GCLs at different relative humidity under isothermal conditions at room temperature for both the wetting and drying path. Consideration is also given to the effect of stress, GCL structure (i.e. differences in geotextiles and bonding of needle-punched fibres to the carrier geotextile) and bentonite form (powdered or granular).

\section{MATERIALS AND METHODS}

\subsection{Materials}

Three commercially available needle-punched GCLs were used in this study to investigate their water vapour sorption/desorption isotherms. Powder sodium bentonite formed the core of GCL-1 and GCL-2; granular sodium bentonite formed the core of GCL-3. GCL-1 and GCL-3 had a nonwoven polypropylene geotextile cover layer and a woven polypropylene geotextile carrier. GCL-2 had a nonwoven polypropylene geotextile cover layer and a nonwoven polypropylene geotextile with a woven scrim reinforcement carrier. The woven sides of GCL-1 and GCL-2 were thermally treated to bond the two geotextiles. The basic physical characteristics of the GCLs are given in Table 1. The mass per unit area of bentonite $\left(M_{\text {bent }}\right)$ was calculated from the difference between the mass per unit area of the GCL $\left(M_{\mathrm{GCL}}\right)$ and the mass per unit area of the geotextiles $\left(M_{\mathrm{geo}}\right) . M_{\mathrm{GCL}}$ and $M_{\text {geo }}$ were obtained on virgin specimens at the laboratory-stored water content condition for GCL-1 and GCL-3 and at as-received water content condition for GCL-2. The peel strength of the GCLs was measured following the procedure outlined in
Table 2. Bentonite properties of GCLs

\begin{tabular}{|l|r|r|r|}
\hline Parameters & GCL-1 & GCL-2 & GCL-3 \\
\hline Particle density (g/cm $\left.{ }^{3}\right)$ & 2.65 & 2.65 & 2.66 \\
Liquid limit (\%) & 498 & 510 & 540 \\
Plastic limit (\%) & 42 & 45 & 51 \\
Plasticity index (\%) & 456 & 465 & 489 \\
Swell index (ml/2 g) & 25 & 25 & 27 \\
Loss on ignition (\%) & 5.32 & 5.17 & 7.39 \\
Cation exchange capacity (cmol/kg) & 67 & 65 & 81 \\
\hline
\end{tabular}

ASTM D6496. The properties of the bentonite components extracted from the GCLs, as measured in the laboratory, are given in Table 2. The Atterberg limits, swell index and loss on ignition were performed following the procedure outlined in ASTM D4318, ASTM D5890 and ASTM D7348, respectively. Measurements of cation exchange capacity (CEC) were made by $\mathrm{BaCl}_{2}$ compulsive exchange method (Sumner and Miller 1996) with Ba analysis by X-ray fluorescence. Mineralogical composition of the bentonite components of the three GCLs is presented in Table 3.

Reagent grade salts (supplied by VWR International Pty Ltd, Australia) were used to create super-saturated solutions by mixing salt with distilled water. The salt assay values indicating the purity of salts are more than $98 \%$ for all salts used in this research, as such the actual RH values may differ by a maximum of $3 \%$ of the reported values (Table 4). A digital four-place electronic balance was used to measure the mass of samples, salts and distilled water.

\subsection{Preparation of RH controlling devices}

To generate constant relative humidity under two different stress conditions, two experimental techniques were employed: (i) a free swell and (ii) a confined (20 kPa) condition. Humidity-controlled containers (Figure 2(a)) were used to perform the free swell tests. Vacuum desiccators (Figure 2(b)) were used to conduct tests under $20 \mathrm{kPa}$ applied stress.

\subsubsection{Humidity-controlled containers}

The humidity-controlled container comprised three components: bottom cylinder, cover containing O-ring and four clips, and specimen-holding unit. The bottom

Table 3. Mineralogical composition of bentonite of GCLs

\begin{tabular}{|l|c|c|c|}
\hline Parameters & GCL-1 & GCL-2 & GCL-3 \\
\hline Quartz (\%) & 12 & 14 & 3 \\
Cristobalite (\%) & 10 & 8 & 2 \\
Montmorillonite (\%) & 74 & 74 & 83 \\
Calcite (\%) & $<1$ & $<1$ & 3 \\
Orthoclase (\%) & - & - & 3 \\
Albite/anorthite (\%) & 4 & 4 & 6 \\
Anatase (\%) & - & - & $<1$ \\
Hematite (\%) & - & - & $<1$ \\
\hline
\end{tabular}

Mineralogical test was done by Mineralogical services, CSIRO Land and Water, South Australia. 
Table 4. Relative humidity of super saturated salts at $20 \pm 1^{\circ} \mathrm{C}$

\begin{tabular}{|c|c|c|c|c|c|}
\hline \multirow[t]{2}{*}{ Super saturated salt } & \multicolumn{5}{|c|}{ Relative humidity (\%) } \\
\hline & $\begin{array}{l}\text { Present study } \\
\text { (WP4C) }\end{array}$ & ASTM E104 & $\begin{array}{l}\text { Delage et al. } \\
\quad(1998)\end{array}$ & $\begin{array}{c}\text { Lide (2009) } \\
\text { (CRC handbook) }\end{array}$ & $\begin{array}{l}\text { Wexler and Hasegawa } \\
\text { (1954) }\end{array}$ \\
\hline $\mathrm{LiBr}$ & $7.09 \pm 0.04$ & $6.4 \pm 0.6$ & - & - & - \\
\hline $\mathrm{LiCl}$ & $11.05 \pm 0.30$ & $11.3 \pm 0.3$ & 12 & $11.31 \pm 0.31$ & 12.4 \\
\hline $\mathrm{CH}_{3} \mathrm{COOK}$ & $22.75 \pm 0.03$ & $22.5 \pm 0.4$ & 20 & - & - \\
\hline $\mathrm{K}_{2} \mathrm{CO}_{3}$ & $44.50 \pm 0.29$ & $43.2 \pm 0.4$ & 44 & $43.2 \pm 0.30$ & - \\
\hline $\mathrm{NaBr}$ & $59.30 \pm 0.50$ & $57.6 \pm 0.4$ & 58 & - & - \\
\hline KI & $70.60 \pm 0.12$ & $68.9 \pm 0.3$ & - & - & - \\
\hline $\mathrm{NaCl}$ & $75.45 \pm 0.15$ & $75.3 \pm 0.2$ & 76 & $75.47 \pm 0.14$ & 75.5 \\
\hline $\mathrm{KCl}$ & $84.95 \pm 0.16$ & $84.2 \pm 0.3$ & 86 & $85.11 \pm 0.29$ & - \\
\hline $\mathrm{KNO}_{3}$ & $93.70 \pm 0.22$ & - & - & - & 93.1 \\
\hline $\mathrm{K}_{2} \mathrm{SO}_{4}$ & $97.70 \pm 0.04$ & $97.3 \pm 0.5$ & 96.5 & $97.6 \pm 0.50$ & 97.1 \\
\hline
\end{tabular}

${ }^{*}$ Values are taken from different sources.

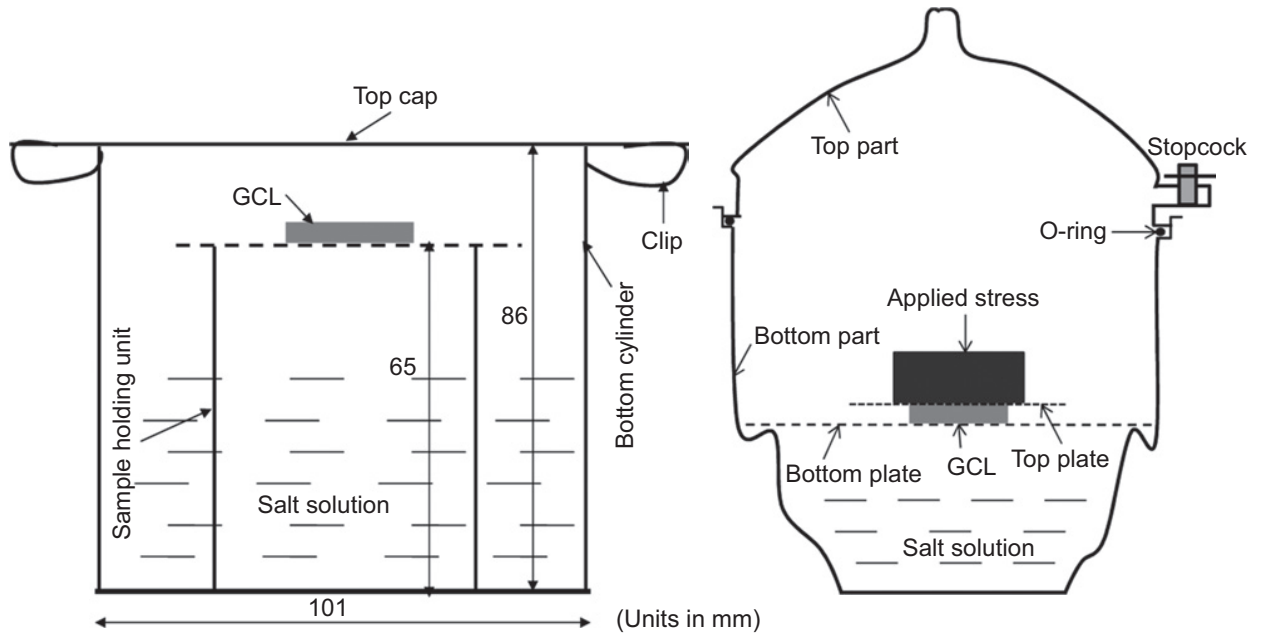

(a)

(b)

Figure 2. Schematic view of (a) humidity-controlled container and (b) vacuum desiccator (not drawn to scale)

cylinder (101 mm average inside diameter and $86 \mathrm{~mm}$ long) contained the salt solution inside the humiditycontrolled container to generate the target RH. The function of the cover was to make the container air tight by means of an O-ring and four clips when attached to the bottom cylinder. The specimen-holding unit was prepared by cutting a polyvinyl chloride (PVC) pipe $(50 \mathrm{~mm}$ diameter, $65 \mathrm{~mm}$ long) and attaching a flywire grid mesh to it by means of a glued tape. The purpose of the specimenholding unit was to provide a flat surface to hold the GCL specimen above the super-saturated salt solution. The schematic of the humidity-controlled containers is shown in Figure 2(a).

\subsubsection{Vacuum desiccators}

The vacuum desiccators consisted of two major parts: upper part and bottom part. The function of the bottom part was to contain the salt solution to maintain constant RH. The upper part was assembled to the bottom part by means of an O-ring to make the dessicator airtight. The inside diameter of the desiccator was $197 \mathrm{~mm}$. A $190 \mathrm{~mm}$ diameter perforated steel bottom plate was fitted on the groove of the desiccator to hold the GCL specimens above the salt solutions. Another perforated top plate was placed on top of the specimens to distribute the applied load uniformly. Details of the desiccator are shown in Figure 2(b).

\subsection{GCL specimen preparation}

A3-sized sheet GCL samples were cut from large GCL rolls using a sharp stainless steel knife. GCL specimens of $30 \mathrm{~mm}$ diameter were then obtained by pressing a steel cutting ring into a sample using a hydraulic press. This technique was employed to obtain uniform and minimally disturbed specimens and to minimise loss of bentonite during specimen cutting. After cutting the specimens, silicon gel ( $Z$ bond 616, Bostik Australia Pty Ltd) was smeared along the periphery to reduce loss of dry bentonite during handling throughout the hydration processes in the humidity-controlled environment. To estimate the amount of smeared silicon gel, the mass of the GCL specimens was recorded before and after coating with the gel. After solidification of the silicon gel, the GCL specimens (Figure 3) were placed within the humiditycontrolled containers/desiccators. As silicon gel is not 


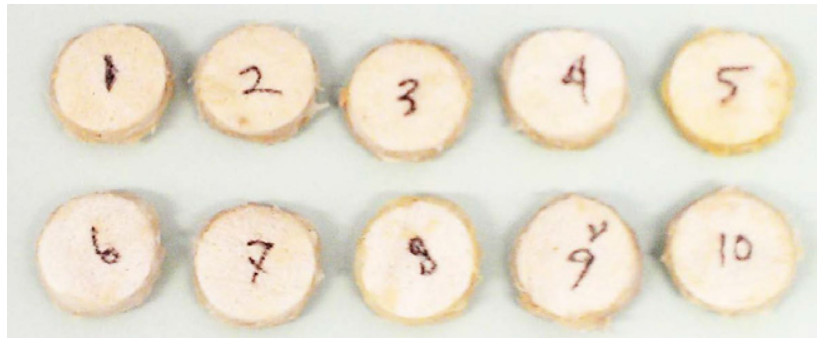

Figure 3. GCL-2 specimens after smearing silicon gel around the exposed bentonite edges

affected by moisture (according to product specification); the mass of the silicon gel was considered to be constant and any moisture loss or gain by the silicon gel was assumed to be insignificant in the experimental process.

\subsection{Preparation of salt solutions}

The salt solutions were prepared according to ASTM E104. Ten salts: $\mathrm{LiBr}, \mathrm{LiCl}, \mathrm{CH}_{3} \mathrm{COOK}$, $\mathrm{K}_{2} \mathrm{CO}_{3}, \mathrm{NaBr}, \mathrm{KI}, \mathrm{NaCl}, \mathrm{KCl}, \mathrm{KNO}_{3}$ and $\mathrm{K}_{2} \mathrm{SO}_{4}$ were used in ten humidity-controlled containers and desiccators, under free swell and $20 \mathrm{kPa}$ stress conditions, to obtain a range of relative humidity. As reported by Rockland (1960), most of the salts used in the present investigation have little variation in $\mathrm{RH}$ in the temperature range of 20 to $30^{\circ} \mathrm{C}$ due to their low thermal coefficients. The mass of solute $(\mathrm{g})$ for $100 \mathrm{~g}$ of water, at $20^{\circ} \mathrm{C}$, can be estimated as given in the CRC Handbook of Chemistry and Physics (Lide 2009)

$$
r_{2}=\frac{100 w_{2}}{1-w_{2}}
$$

where $w_{2}$ is the solubility expressed in mass percentage of solute. The $w_{2}$ values for salts were taken from Lide (2009) for $20^{\circ} \mathrm{C}$ and then the minimum amount of salt required to prepare a saturated solution was calculated using Equation 1. About $50 \%$ more salt was added to ensure that the solution remained super-saturated and to avoid any potential change in concentration during adsorption or desorption of water. This was considered sufficient to maintain a constant $\mathrm{RH}$ condition within the closed containers/desiccators throughout the duration of the experiments.

Prepared super-saturated salt solutions were kept in sealed containers/desiccators overnight for temperature and relative humidity equilibration. Standard suction measurement equipment (WP4C dew point potentiometer; Decagon Devices, USA; range: 0-300 MPa; accuracy: $\pm 0.05 \mathrm{MPa}$ from 0 to $-5 \mathrm{MPa}$ and $1 \%$ from -5 to $-300 \mathrm{MPa}$ ) was used to calculate the relative humidity (Equation 3) of the super-saturated salt solution from measured total suction values. This device utilises the chilled-mirror dew point technique to measure the relative humidity of the specimen and to calculate suction based on Kelvin's law (Equation 2)

$$
\psi_{\mathrm{t}}=-\frac{R T}{v M} \ln \left(\frac{\mathrm{RH} \%}{100}\right)
$$

or

$$
\mathrm{RH} \%=100 \times \exp \left(-\frac{\psi_{\mathrm{t}} v M}{R T}\right)
$$

where $\psi_{\mathrm{t}}$ is the total suction $(\mathrm{Pa}), R$ is the universal gas constant $(8.31432 \mathrm{~J} / \mathrm{mol}$ per $\mathrm{K}), T$ is absolute temperature $(\mathrm{K}), v$ is the specific volume of water (i.e. reciprocal of density, $\mathrm{m}^{3} / \mathrm{kg}$ ), $M$ is the molecular mass of water vapour $(18.016 \mathrm{~kg} / \mathrm{kmol})$ and $\mathrm{RH}$ is the relative humidity in the containers/desiccators (\%).

The relative humidity was back-calculated using Kelvin's law from measured total suction values as shown in Equation 3. The relative humidity estimated for the super-saturated salt solutions was comparable to the relative humidity reported in Wexler and Hasegawa (1954), Delage et al. (1998), ASTM E104 and CRC Handbook (Lide 2009) (Table 4).

All the experiments were conducted in a carefully controlled room $\left(17 \mathrm{~m}^{2}\right)$ at $20 \pm 1^{\circ} \mathrm{C}$ and relative humidity of $52 \pm 2 \%$. The temperature of the experimental room was controlled using a Kogan 12000 BTU portable air conditioner which is suitable for $25 \mathrm{~m}^{2}$ area. Regular monitoring of temperature and $\mathrm{RH}$ of the room was maintained during the experimental period using a calibrated RH and temperature transmitter (HMT 333; Vaisala, Finland). Manufacturer supplied, sealed, as-received rolls of GCL-1 and GCL-3 were stored in the same room at the same temperature and $\mathrm{RH}$ condition in which the experiments were carried out. GCL-2 was used immediately on arrival to the laboratory. Therefore, the initial ambient conditions of the three GCL samples can be considered to have been stable and approximately equivalent to the $52 \% \mathrm{RH}$ condition. However, it is not known how transportation affected the as-received condition.

The relative humidity change above the super-saturated salt solution was less than $0.5 \%$ with respect to temperature fluctuating between 19 and $21^{\circ} \mathrm{C}$ (Table 4). Therefore, the variation of $\mathrm{RH}$ within the humidity-controlled containers and vacuum desiccators with room temperature fluctuation was considered to be negligible and hence not considered for further analyses.

\subsection{Test method}

To confirm that the containers were adequately sealed, three different evaporation loss conditions at room temperature were investigated for 30 days. These were sealed containers: (1) without re-sealable plastic bag; (2) within a single re-sealable plastic bag; and (3) within double re-sealable plastic bags. To verify if possible moisture losses occurred due to evaporation, containers were filled with distilled water and mass losses were recorded. The three conditions tested indicated that the container without a plastic bag, with a single and with a double plastic bag lost, $0.2,0.05$ and $0.00 \%(0.5,0.15$ and $0.00 \mathrm{~g})$ of moisture, respectively, due to evaporation. Therefore, the double re-sealable plastic bag option was used in this study. 
The specimen was placed on the top base/plate of the humidity-controlled containers/desiccators, which was placed in its turn above the prepared salt solution at the bottom surface of the container/desiccator under either free swell or $20 \mathrm{kPa}$ applied stress condition (Figure 2). Periodic mass measurements were conducted to quantify the water vapour adsorbed/desorbed behaviour from the initial water content with time. The mass measurement was done within very short period of time $(<30 \mathrm{~s})$ in the experimental room and containers/desiccators were kept open for even less than $10 \mathrm{~s}$ during removal and replacement of the specimens from/into containers/desiccators at the time of mass measurement processes. It was assumed that the laboratory conditions had little effect on either the mass of the specimen or the concentration of the salt solution (super saturated) during the short time periods in which the containers/desiccators were opened. It was considered that the use of a large excess of salt in the saturated salt solutions ensured that the specimen re-attained the equilibrium relative humidity soon after replacing it in the humidity-controlled containers/desiccators. Therefore, the opening of the container/desiccator was assumed to not affect the adsorption or desorption rate of the GCLs significantly. The initial gravimetric water content of the GCLs used in this study varied between $\sim 7$ and $\sim 13 \%$. When the specimens reached mass equilibrium, their water content was measured. The thickness of the specimen was measured using a caliper by taking the average of four measurements at four different locations in the GCL specimen.

\section{RESULTS AND DISCUSSION}

\subsection{Effect of relative humidity, GCL structure, bentonite form and stress during adsorption}

The time-dependent GCL water adsorption isotherms are plotted in Figure 4 under free swell $(0 \mathrm{kPa})$ and $20 \mathrm{kPa}$ stress conditions at $\mathrm{RH}$ values greater than ambient $\mathrm{RH}(>52 \pm 2 \%)$ starting from the initial GCL gravimetric water content. Water adsorption from medium to high RH $(<90 \%)$ under both 0 and $20 \mathrm{kPa}$ stress are shown in Figures 4(a) to 4(c) for GCL-1, GCL-2 and GCL-3, respectively. Additionally, Figures 4(d) to 4(f) present water adsorption against elapsed time for higher $\mathrm{RH}$ (>90\%) under the same stress conditions.

All GCL specimens (GCL-1, GCL-2, GCL-3) adsorbed water vapour and reached equilibrium water contents under both stress conditions (free swell and $20 \mathrm{kPa}$ ) (Figures 4(a) to 4(f)) and the absolute quantity increased as the RH increased from 59.30 to $97.70 \%$ under both stress conditions for all the GCLs. Water adsorption was higher for free swell specimens in comparison with specimens under $20 \mathrm{kPa}$ stress for all three GCLs due to the reduction of pore spaces in these specimens at the higher stress condition. Therefore, it is evident from Figure 4 that equilibrated RH and applied stress affect the water adsorption behaviour of the GCLs.

When the GCL specimens were equilibrated at $\mathrm{RH}>$ $52 \pm 2 \%$ (above ambient $\mathrm{RH}$ ), water adsorption did not differ much for GCL-1 (woven carrier geotextile, Figures 4(a) to 4(d)) and GCL-2 (nonwoven with woven scrim-reinforced carrier geotextile, Figures 4(b)-4(e)) under either stress condition. Despite the presence of the scrim reinforcement the reduction in water adsorption of GCL-2 was less evident in comparison with GCL-1. This is probably because there was negligible swelling of GCL specimens in this $\mathrm{RH}$ range with an equilibrated water content $<34 \%$. GCL-3 (granular sodium bentonite, Figures 4(c) to 4(f)) adsorbed more water than GCL-1 (powdered sodium bentonite and thermally treated GCL, Figures 4(a) to 4(d)) under both free swell and $20 \mathrm{kPa}$ stress conditions for $\mathrm{RH}$ ranging between 59.30 and $97.70 \%$ during the adsorption process. The increase of water adsorption in GCL-3 in comparison with GCL-1 may be due to the combined effect of the bentonite form and different bentonite mineralogy (Table 3). Vangpaisal and Bouazza (2004), Rayhani et al. (2011) and Bouazza et al. (2013) reported that thermal treatment can restrict the swelling of GCL and thus can reduce the GCL water adsorption; however, the level of hydration $(<35 \%)$ in all these cases was so low that this was unlikely to be a factor at the water contents examined herein. On the other hand granular bentonite GCL can adsorb more water compared to powdered bentonite GCL due to the difference in the size of the pore spaces and their interconnectedness. Granular forms of bentonite contain a more continuous pore size distribution than powdered bentonites and the larger pores in the granular bentonite allow water vapour to move more effectively through the bentonite than the powder bentonite and hence increases the uptake at the relative humidity values examined (Vangpaisal and Bouazza 2004). Furthermore, the higher montmorillonite content in GCL-3 (83\% in comparison with $74 \%$ in GCL-1) may have contributed to the higher water adsorption observed in GCL-3. This is in agreement with the findings of Likos and $\mathrm{Lu}$ (2002) and Akin and Likos (2014) who reported that the water adsorption of clay mixtures increased with increasing montmorillonite content. Therefore, it can be concluded that the water adsorption of GCL-1 and GCL-2 was only minimally affected by the presence of a woven scrim-reinforcement carrier. This was interpreted as being due to the low range of moisture content achieved through vapour equilibrium technique. The effect of bentonite form and mineralogy (GCL-1 and GCL-3) was noticeable on the water adsorption behaviour at $\mathrm{RH}>52 \pm 2 \%$.

\subsection{Effect of relative humidity, GCL structure, bentonite form and stress on equilibration time during adsorption}

The equilibration times differed for different $\mathrm{RH}$ values for all three GCLs during the water vapour adsorption process. For example, at $\mathrm{RH}$ ranging from 59.30 to $84.95 \%$ (Figures 4(a) to 4(c)) GCL specimens reached equilibrium very rapidly (about $1-2$ days) for all three GCLs under both 0 and $20 \mathrm{kPa}$ stress conditions. At $93.70 \% \mathrm{RH}$, about 5 days were needed to reach water content equilibrium under both free swell and $20 \mathrm{kPa}$ stress conditions (Figures 4(d)-4(f)). However, for all three GCLs held at $97.70 \%$ RH both free swell and $20 \mathrm{kPa}$ stress 


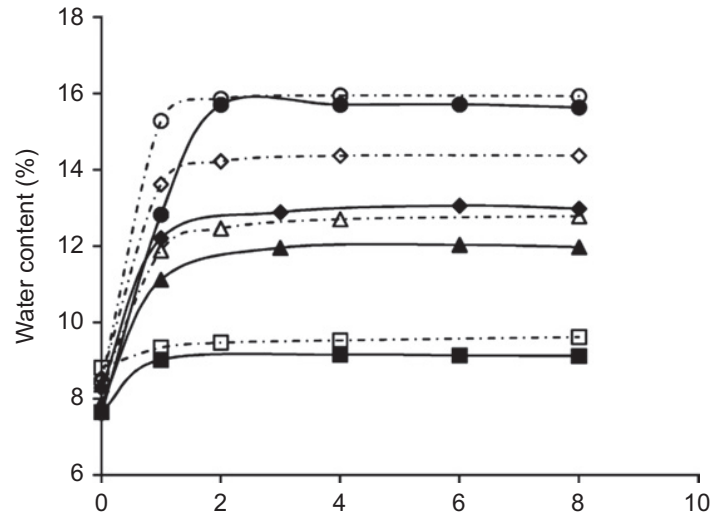

(a)

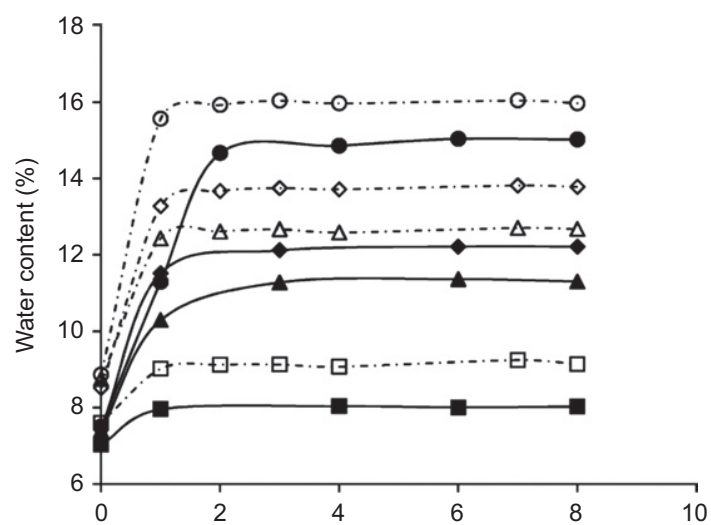

(b)

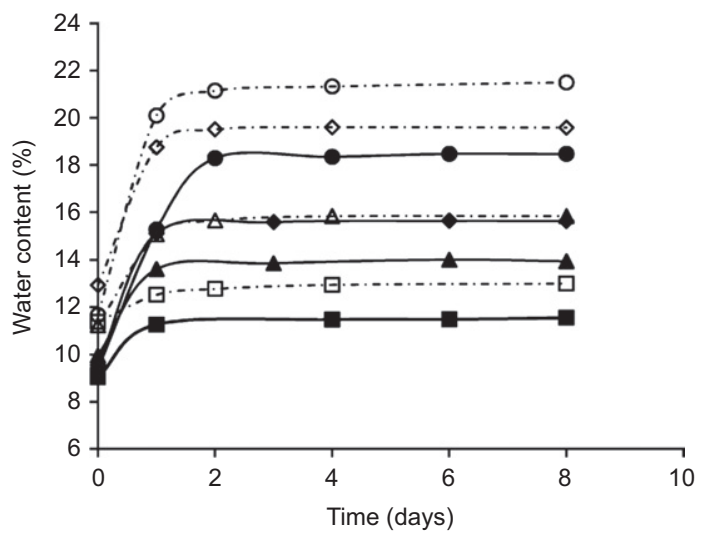

(c)

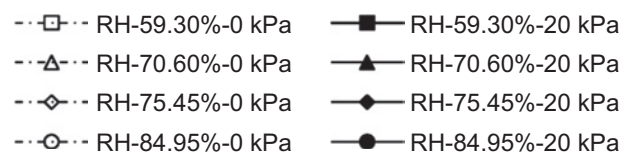

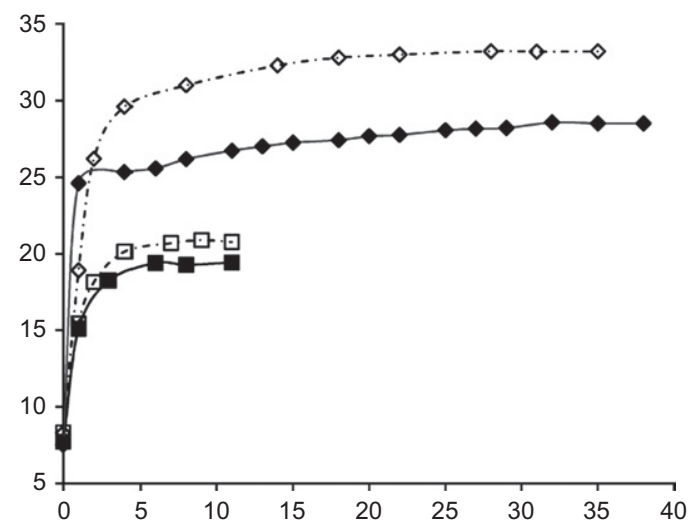

(d)

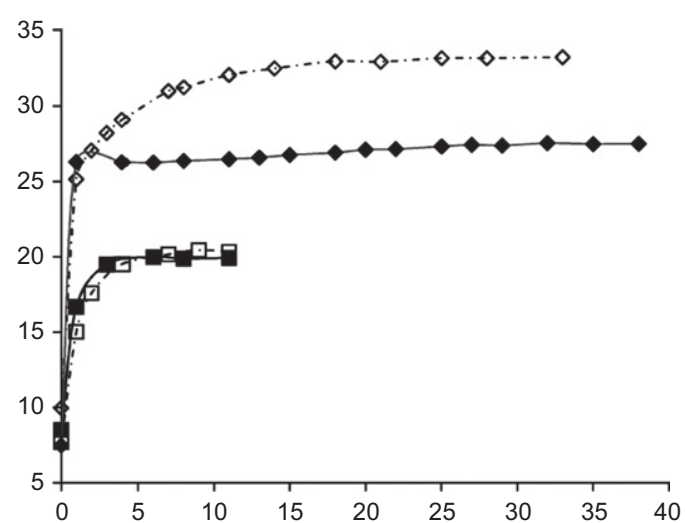

(e)

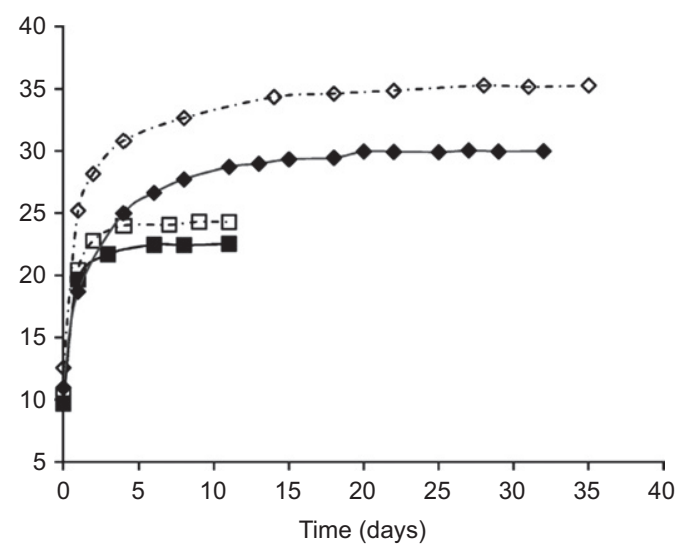

(f)

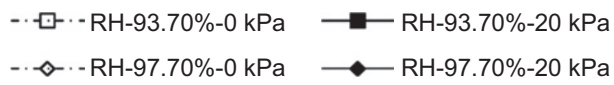

Figure 4. Gravimetric water content with respect to time at different RH under free swell and $20 \mathrm{kPa}$ for (a) GCL-1, (b) GCL-2 and (c) GCL-3 at RH < 90\%, and for (d) GCL-1, (e) GCL-2 and (f) GCL-3 at RH>90\% during adsorption

specimens took about 20-30 days to achieve equilibration (Figures 4(d) to 4(f)). At RH > 84.95\%, GCLs absorb water to fill the low water potential bentonite pores from the vaporised environment through a diffusion process (slow process), thereby taking more time to equilibrate when $\mathrm{RH}$ increased. Therefore, it can be inferred from Figure 4 that the GCL structure (i.e. difference in geotextiles and bonding of needle-punched fibres to the carrier geotextile), bentonite form (powder or granular) and applied stress had little or no effect on the equilibration time of the GCL during adsorption in the $\mathrm{RH}$ range of $59.30-97.70 \%$ (noting that all correspond to water contents $\leq 35 \%$ gravimetric which were very low for these GCLs).

\subsection{Effect of relative humidity, GCL structure, bentonite form and stress during desorption}

Time-dependent water vapour desorption isotherms $(\mathrm{RH}<52 \pm 2 \%$ ) for GCL-1, GCL-2 and GCL-3 are 


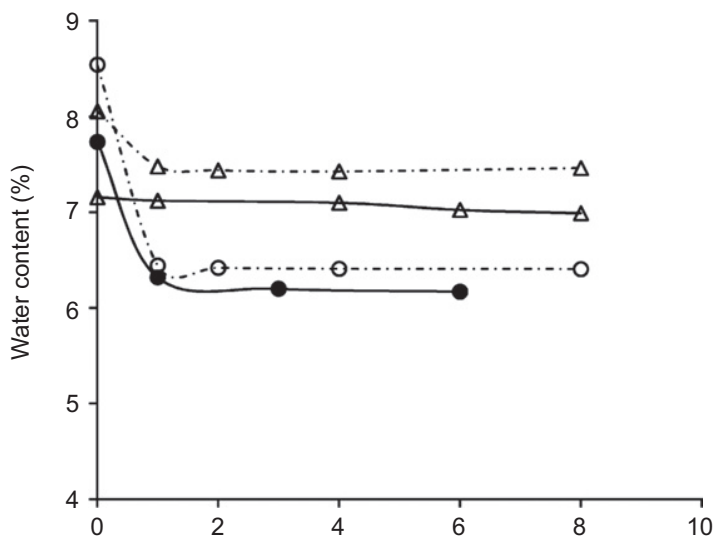

(a)

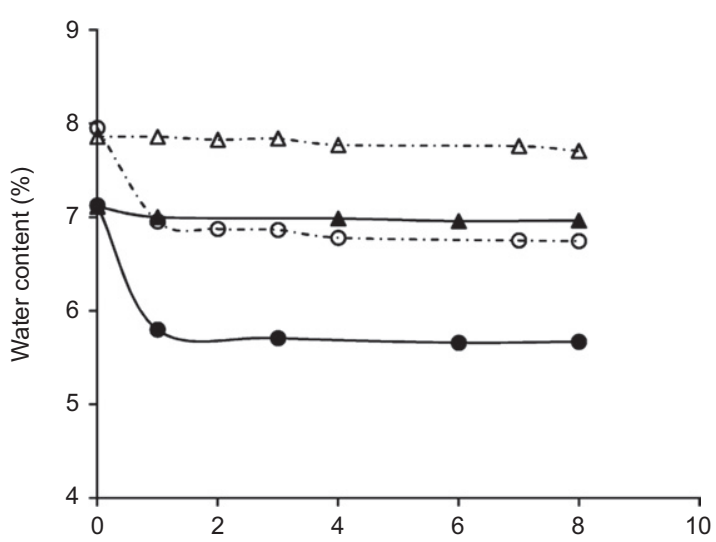

(b)

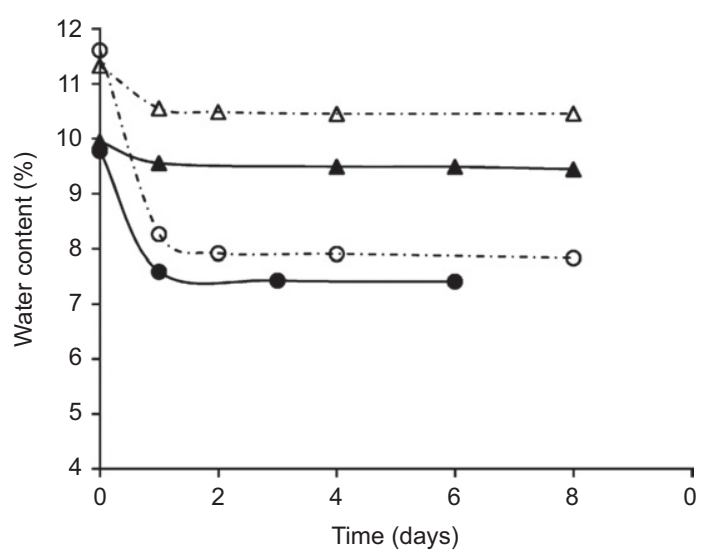

(c)

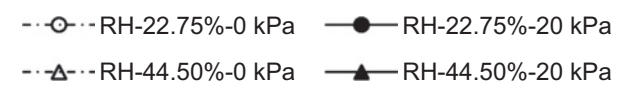

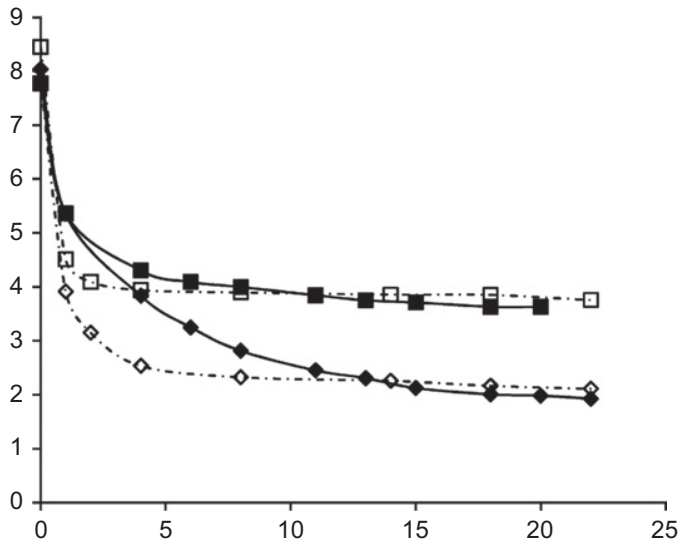

(d)

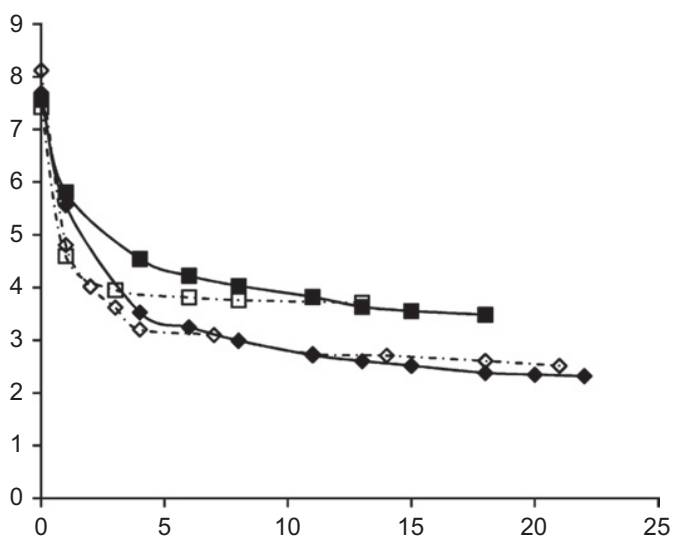

(e)

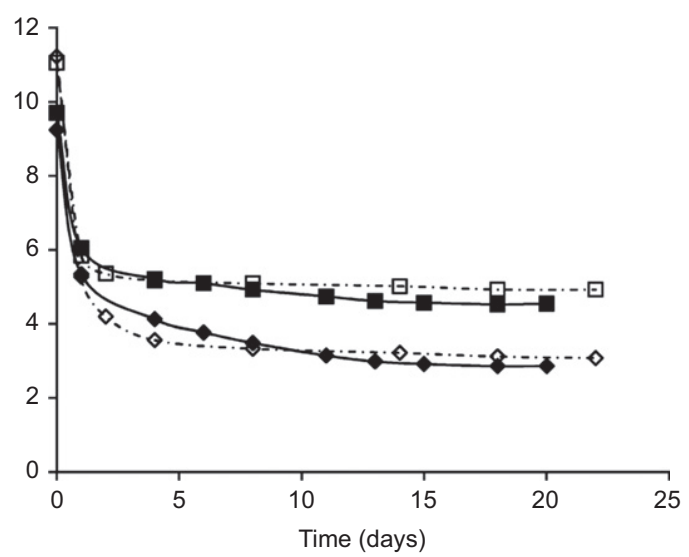

(f)

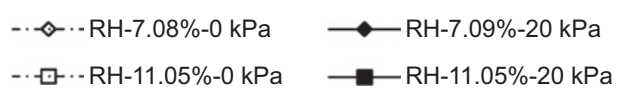

Figure 5. Gravimetric water content against time at different RH during desorption under free swell and $20 \mathrm{kPa}$ for (a) GCL-1, (b) GCL-2 and (c) GCL-3 at RH $>20 \%$, and for (d) GCL-1, (e) GCL-2 and (f) GCL-3 at RH $<20 \%$

plotted in Figures 5(a) to 5(c), respectively, at 22.75 and $44.50 \% \mathrm{RH}$, and in Figures 5(d) to 5(f), respectively, at 7.09 and $11.05 \% \mathrm{RH}$ under free swell $(0 \mathrm{kPa})$ and $20 \mathrm{kPa}$ stress conditions starting from the initial (off-the-roll) gravimetric water content.

A reduction of the gravimetric water content occurred at $\mathrm{RH}<52 \pm 2 \%$ in all GCL specimens shown in Figure 5. The water desorption increased as $\mathrm{RH}$ decreased from 44.50 to $7.09 \%$ for the two stress conditions. At the same $\mathrm{RH}$, equilibrated gravimetric water content was higher in free swell specimens in comparison with specimens subjected to a $20 \mathrm{kPa}$ stress. These reductions in water content may be due to the presence of less pore space in higher stressed specimens compared with free swell specimens. Therefore, it can be implied from Figure 5 that RH and applied stress dominated the water desorption behaviour of GCLs.

When the GCL specimens were equilibrated at $\mathrm{RH}<52 \pm 2 \%$, the variation of water desorption was small for GCL-1 (woven carrier, Figures 5(a) to 5(d)) and 
GCL-2 (nonwoven with woven scrim-reinforced carrier, Figures 5(b) to 5(e)) for almost all RH under both stress conditions. The behaviour in water desorption of GCL-1 and GCL-2 was similar and indicated that the woven scrim-reinforced carrier in GCL-2 was unable to reduce drying of the bentonite in the $\mathrm{RH}$ range studied for desorption. However, GCL-3 (granular sodium bentonite, Figures 5(c) to 5(f)) was found to retain more water compared to GCL-1 (powdered sodium bentonite, Figures 5(a) to 5(d)) under both free swell and $20 \mathrm{kPa}$ stress conditions for all $\mathrm{RH}$ examined during desorption. This result is in agreement with Beddoe et al. (2011) who showed that a GCL with coarse granular bentonite retained more water in comparison with a GCL with fine granular bentonite under the drying path. In addition the presence of higher montmorillonite content in GCL-3 allowed more water retention during the desorption process as indicated in the study reported by Akin and Likos (2014). Thus, the increase in water retention for GCL-3 observed in the present study was mainly due to the mutual contribution of the bentonite form in addition to the mineralogy of the bentonite. Therefore, similar to adsorption, it can also be inferred that the water desorption behaviour of GCL-1 and GCL-2 with time was minimally affected by the GCL structure for materials using the same bentonite form when $\mathrm{RH}<52 \pm 2 \%$. However, bentonite form and mineralogy tended to affect the water desorption behaviour at $\mathrm{RH}<52 \pm 2 \%$, for GCLs with different bentonite form and mineralogy (GCL-1 and GCL-3).

3.4. Effect of relative humidity, GCL structure, bentonite form and stress on equilibration time during desorption

Similar to the adsorption isotherms, the desorption isotherms also indicated variation in the times required to reach equilibration at different $\mathrm{RH}$ for all GCL specimens. Specimens placed at RH ranging from 44.50 to $22.75 \%$ (Figures 4(a) to 4(c)) reached equilibrium very quickly (within 1 day) for all three GCLs under both free swell and the $20 \mathrm{kPa}$ stress condition. However, specimens at 11.05 and $7.09 \% \mathrm{RH}$ required about 3 and
8 days, respectively, to reach equilibrium (Figures $5(\mathrm{~d})$ to $5(\mathrm{f}))$ under free swell condition whereas under the $20 \mathrm{kPa}$ stress condition, they took about 13 and 18 days, respectively (Figures 5(d) to 5(f)). At low RH $(\leq 11.05 \%)$ the GCLs needed more time to reach equilibrium as the GCLs had to expel strongly bonded water from the small pores of bentonite through diffusion. For this range of RH values $(\mathrm{RH} \leq 11.05 \%)$, the equilibration time increased as the controlled RH was reduced. Moreover, $20 \mathrm{kPa}$-stressed specimen tended to take more time to equilibrate in comparison with the free swell specimens, probably due to the reduction of GCL bentonite pore diameter and disruption of the pore network at a higher stress. Therefore, it can be concluded that both $\mathrm{RH}$ and applied stress affected the equilibration time of GCLs at $\mathrm{RH} \leq 11.05 \%$ during desorption. However, the effect of the GCL structure and bentonite form on equilibration time was negligible during the desorption process.

\subsection{Effect of relative humidity, GCL structure and bentonite form on adsorption/desorption isotherm}

The mass-dependent water adsorption isotherms for the three GCLs at equilibrium is plotted against relative humidity in Figures 6(a) and 6(b) under the free swell and $20 \mathrm{kPa}$ stress conditions, respectively. Water adsorption ( $\mathrm{mg} / \mathrm{g}$ ) was quantified by dividing the amount of adsorbed water by the mass of the dry bentonite present in the GCL. The water adsorption/desorption test was performed on the GCL specimens but the GCL dry bentonite mass was estimated by deducting the geotextile mass from the total GCL mass, similar to the method reported by Vangpaisal and Bouazza (2004) and Rouf et al. (2014a). It was assumed that the geotextile component of GCL did not adsorb any water and so all the water was assumed to be adsorbed by the bentonite component. Nahlawi et al. (2007) reported that the whole range of the geotextile water retention curve varied between 0.1 and $10 \mathrm{kPa}$ suction (log scale) and they also documented that residual water content of the geotextiles occurred at a suction value of less than $10 \mathrm{kPa}$. Therefore, the geotextile

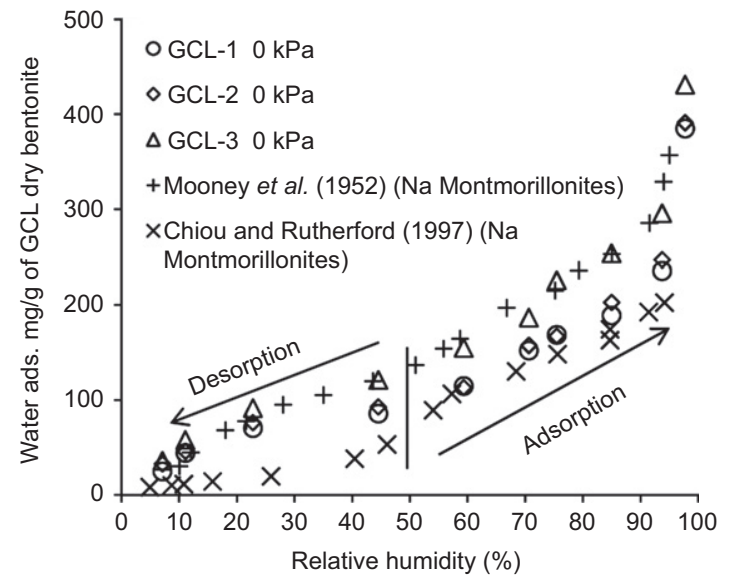

(a)

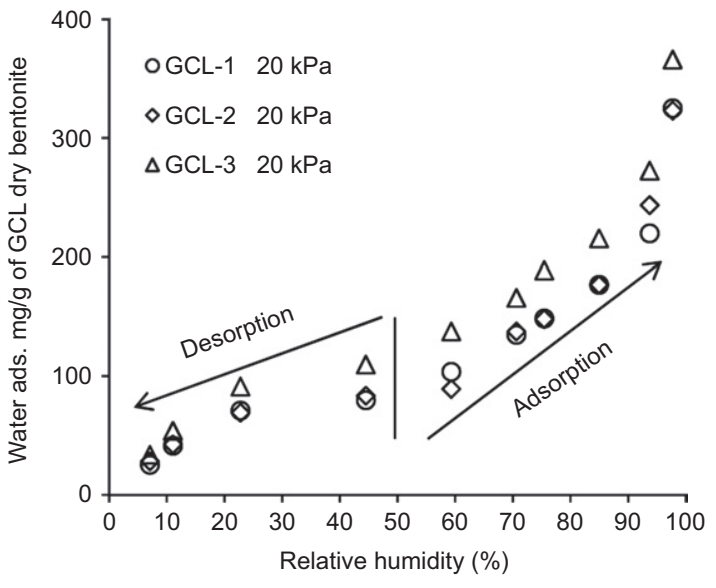

(b)

Figure 6. Water adsorption in mg per g of GCL dry bentonite against RH under (a) free swell and (b) 20 kPa stress conditions for GCL-1, GCL-2 and GCL-3 
component of GCLs was unlikely to take up significant quantities of water at suction $23.15 \mathrm{MPa}(\mathrm{RH} \leq 97.7 \%)$, used in this investigation. Data from Mooney et al. (1952) for sodium montmorillonite (desorption isotherm) and Chiou and Rutherford (1997) for sodium montmorillonites (adsorption isotherm) were also included for comparative purposes. The water adsorption of the bentonite of the GCLs increased with increased equilibrium RH of the GCL specimens under both free swell (Figure 6(a)) and $20 \mathrm{kPa}$ stress (Figure 6(b)) condition. The observed desorption isotherms $(<52 \pm 2 \% \mathrm{RH})$ for $\mathrm{Na}$ bentonite of all three GCLs (Figure 6(a)) compared well with the desorption data for $\mathrm{Na}$ montmorillonite reported by Mooney et al. (1952). In addition, the present adsorption isotherm data $(>52 \pm 2 \% \mathrm{RH})$ for the $\mathrm{Na}$ bentonite of GCL-1 and GCL-2 agreed well with the adsorption isotherm for sodium montmorillonites (Chiou and Rutherford 1997). The water adsorption for GCL-3 was higher in comparison with GCL-1 data, presumably due to the presence of more inter-particle pores in the bentonite granules of GCL-3 compared with the bentonite powder of GCL-1 (Figures 6(a) and 6(b)). GCL-3 adsorbed more water in comparison with GCL-1 as the former provided a more continuous inter-particle pore distribution. Furthermore, GCL-1 was thermally treated which means it should have better anchorage of the fibres compared with GCL-3. This was shown to reduce the water adsorption capacity in GCL-1 due to a reduction of swelling as explained by Rayhani et al. (2011). However, GCL-1 and GCL-2 adsorbed similar amounts of water under both free swell (Figure 6(a)) and $20 \mathrm{kPa}$ (Figure 6(b)) stress conditions over the range of RH investigated in the present study. Therefore, it can be inferred that the bentonite form dominated the water adsorption process, but there was very little variation of water adsorption with GCL geotextile structure over the range of water contents/RH examined (gravimetric water contents $<35 \%$ ). The desorption process was also governed by the same factors as discussed above.

\subsection{Effect of stress on adsorption/desorption}

The variation of gravimetric water content against relative humidity under two different stress conditions is presented in Figure 7 for all GCLs under the equilibrium condition. It can be observed from Figure 7(a) that the effect of stress was insignificant at RH less than $85 \%(84.95 \%)$ in GCL-1. A slight stress effect was observed beyond this range. Below $97.7 \% \mathrm{RH}$, the stress had little effect on the adsorption/desorption behaviour of GCL-2 (Figure 7(b)). For GCL-3 (Figure 7(c)) however, the effect of applied

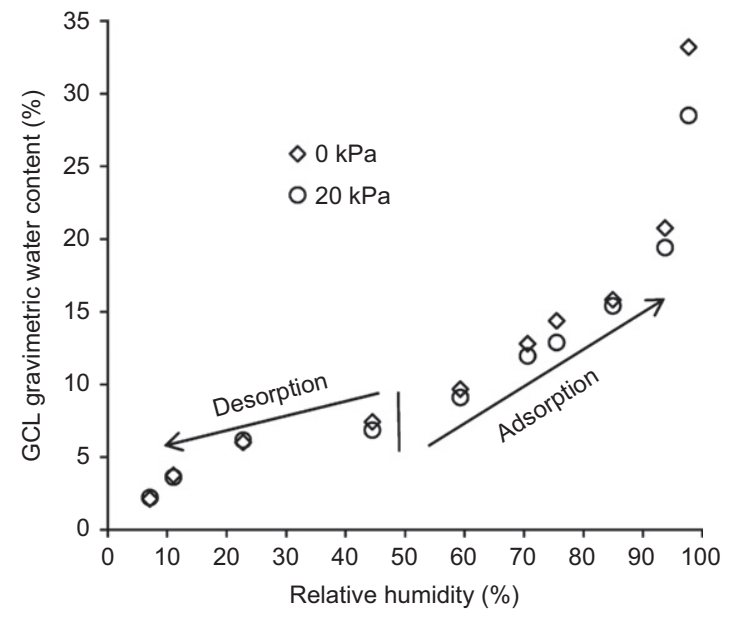

(a)

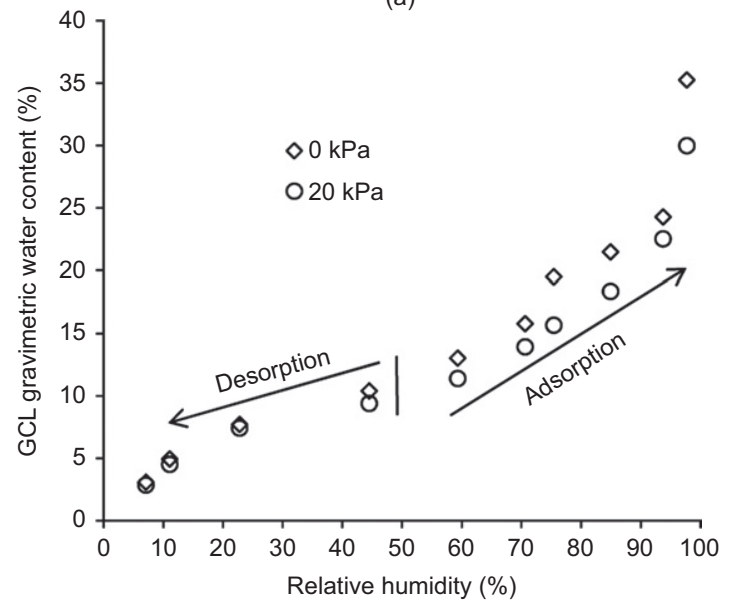

(c)

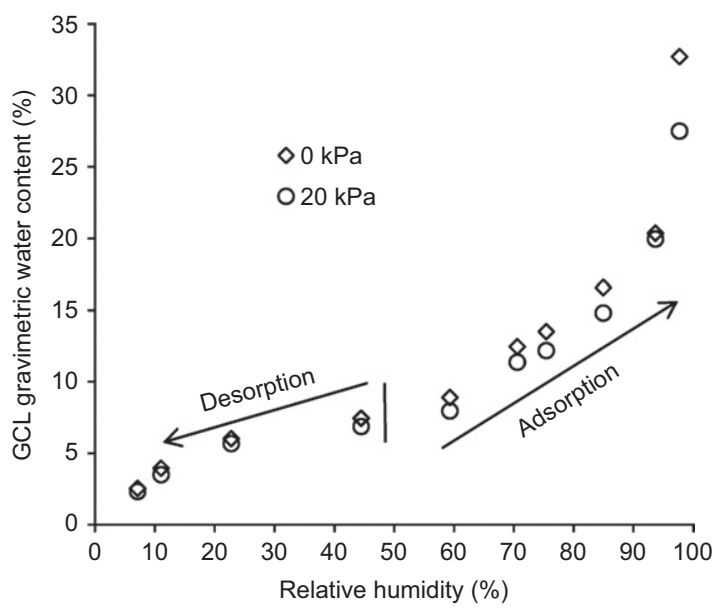

(b) 
stress was pronounced at $\mathrm{RH}>44.5 \%$ due presumably to the reduction of pore spaces and inter-connected pores. The effect of stress observed in Figure 7(c) was confirmed by testing duplicate GCL-3 specimens with similar mass per unit area at a relative humidity of $84.95 \%$ as shown in Figure 8. Specimens 1 and 2 under free swell condition adsorbed the same amount of water (10.5\%) at $84.95 \%$ RH controlled environment at equilibrium. Similarly, specimens 1 and 2 adsorbed the same amount of water $(9 \%)$ under $20 \mathrm{kPa}$ stress condition at equilibrium which confirms the applied stress effect observed in Figure 7(c) for GCL-3.

\subsection{GCL water adsorption at $100 \% \mathbf{R H}$}

Specimens of all three GCLs were tested with distilled water at $\mathrm{RH}=100 \%$ instead of a super-saturated salt solution under both free swell and $20 \mathrm{kPa}$ stress conditions to quantify the water adsorption behaviour in an extremely high humidity environment. Water content is plotted against elapsed time for all three GCLs under free swell (Figure 9(a)) and $20 \mathrm{kPa}$ stress conditions (Figure 9(b)).

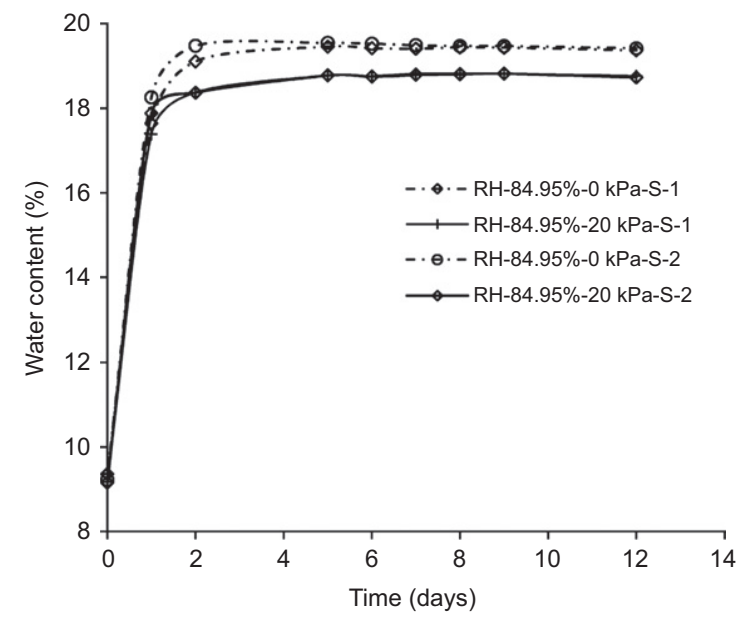

Figure 8. Gravimetric water content against time for GCL-3 at $84.95 \%$ RH under free swell and $20 \mathrm{kPa}$ stress conditions (S-1, sample 1 and S-2, sample 2)

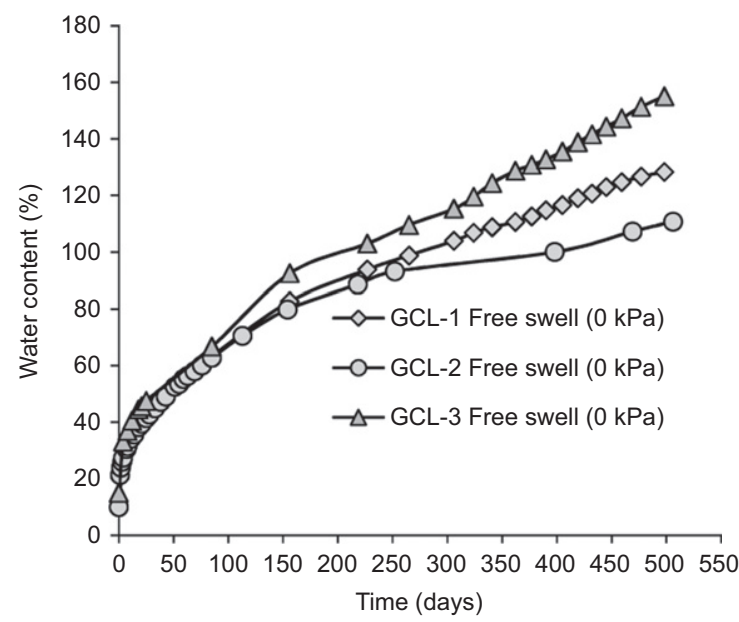

(a)
These tests show that under free swell (Figure 9(a)) condition GCL-1, GCL-2 and GCL-3 reached approximately 128, 112 and 155\% water content (a gain of approximately $102-140 \%$ water content in comparison with the off-the-roll specimens), respectively, after about 500 days of exposure (but still have not reached equilibrium). In contrast, under $20 \mathrm{kPa}$, they reached water contents of approximately 55, 45 and 61\%, respectively (a gain of only $36-46 \%$ water content in comparison with the off-the-roll specimens) after about 335 days exposure and had either reached (GCL-2) or appeared to be approaching equilibrium. GCL-3 consistently gained more moisture due to its structure and the bentonite form (this does not necessarily mean better GCL performance as it is the degree of saturation rather than the actual water content that is more critical to GCL performance; Rowe 2014). The rate of water adsorption was higher in the first few weeks and then water adsorption rate gradually slowed for all three GCLs (Figure 9) with the increase of testing time for both free swell and $20 \mathrm{kPa}$ stress. Furthermore, at $20 \mathrm{kPa}$ stress, GCL-2 reached equilibrium after about 175 days whereas GCL-1 and GCL-3 were still adsorbing water from the vaporised environment under the same stress but their water adsorption rate had sufficiently reduced with testing time (Figure 9(b)). However, under $0 \mathrm{kPa}$ stress condition, all the GCLs were still adsorbing water from the controlled $100 \%$ humidity environment after 500 days. GCL-2 required less equilibration time at $20 \mathrm{kPa}$ than under free swell (Figure 9). This behaviour may be due to the swelling characteristics of the GCL under the two stress conditions applied. At 100\% RH, GCL tends to swell more under free swell conditions in comparison with the $20 \mathrm{kPa}$ stress conditions. Therefore, application of a $20 \mathrm{kPa}$ stress will tend to reduce the available pore spaces quickly and slow down water uptake whereas free swell specimen will keep absorbing water and swelling continuously until the equilibrium condition has been achieved. Figure 9 also shows that there was a large difference in water content variation with time under free swell and $20 \mathrm{kPa}$ stress for all GCLs, indicating that at $\mathrm{RH}=100 \%$ the stress effect was more pronounced on the

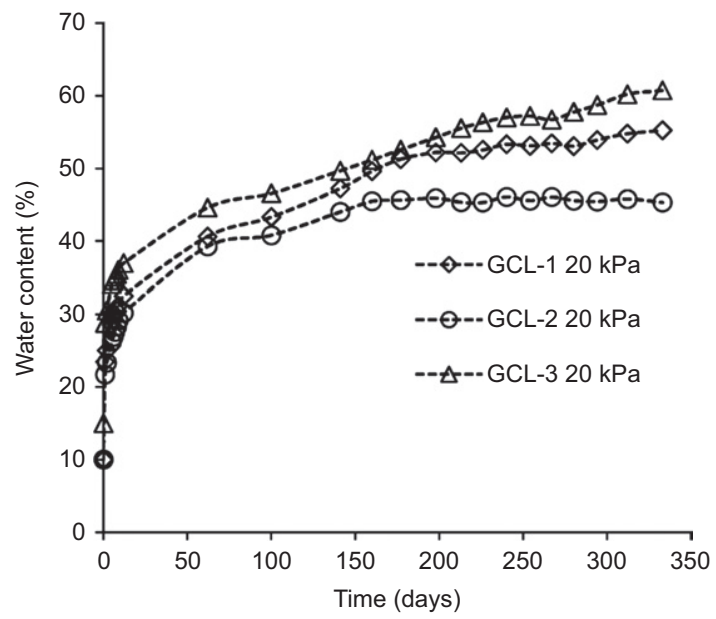

(b)

Figure 9. Gravimetric water content with respect to time under (a) free swell and (b) $20 \mathrm{kPa}$ stress conditions for three GCLs at $100 \% \mathrm{RH}$ 
adsorption process. Figure 9 shows that GCL-3 (woven carrier not thermally treated) adsorbed more water than GCL-1 (woven carrier but thermally treated) which, in turn, absorbed more than GCL-2 (scrim-reinforced nonwoven carrier and thermally treated) at both stress levels, showing that in addition to the effect of bentonite form and mineralogy evident at low water contents ( $\mathrm{RH}<98 \%$ ), the effects of carrier geotextile and thermal treatment become apparent at $100 \% \mathrm{RH}$. Interestingly, the present results contrast with the results reported by Abuel-Naga and Bouazza (2010) who showed that water vapour circulation using a peristaltic pump on a $100 \mathrm{~mm}$ diameter GCL specimen similar to GCL-1 was unable to increase its water content beyond $25 \%$ after almost 1 year of testing. One of the reasons for obtaining lower final water content was the use of larger-sized $(100 \mathrm{~mm}$ diameter) specimen. Another reason is probably that continuous air circulation reduced the equilibration time in comparison with the closed vapour equilibrium technique system, as used in the current investigation, and at the same time, also reduced the final water content of the specimen due to the increase of suction under the forced flow condition (Pintado et al. 2009). These results highlight the extreme sensitivity of the GCL to hydration over RH ranges between 97 and 100\% and how only an apparently small variation in $\mathrm{RH}$ from $100 \%$ can have a large effect on hydration.

\section{CONCLUSION}

The super-saturated salt solution generated vapour phase gave consistent moisture adsorption/desorption isotherm under both free swell and $20 \mathrm{kPa}$ stress conditions at different RH values. It is evident that the specimen $\mathrm{RH}$ and applied stress controlled the water vapour adsorption/ desorption behaviour.

(1) The GCL specimen equilibration time was affected by $\mathrm{RH}$, especially at high RH during water adsorption and at lower RH during desorption. The GCL equilibration time during desorption was only governed by applied stress at the lowest RH $(\leq 11.05 \%)$.

(2) The equilibration time was largely un-affected by GCL type (based on manufacturing process, geotextile structure and thermal treatment) and the bentonite form of GCLs in both the adsorption and desorption processes at the GCL water content $(\leq 35 \%)$ attained over the saturated salt solutions $(\mathrm{RH} \leq 97.7 \%)$.

(3) The water adsorption of the powdered $\mathrm{Na}$ bentonite agreed well with results from literature data for sodium montmorillonites.

(4) For $\mathrm{RH} \leq 97.7 \%$, the effect of stress on adsorption/ desorption in terms of gravimetric water content was small for GCL-1 and GCL-2, whereas the effect of stress on adsorption was more pronounced at high RH for GCL-3 in terms of gravimetric water content. The effect of GCL geotextile structure (scrim reinforcement) on hydration was insignificant for $\mathrm{RH} \leq$
97.7\%). However, bentonite form and mineralogy of GCLs affected the adsorption/desorption of GCLs significantly at $\mathrm{RH} \leq 97.7 \%$.

(5) The results of the present study also suggest that at high RH the effect of stress was more pronounced compared with low RH. The findings of the study showed that up to $97.7 \% \mathrm{RH}$ (where the GCL was in poor contact with wet subsoil or where less moist subsoil was present below the GCL), the GCLs were not able to take up enough water to work as an effective hydraulic barrier under either free swell or $20 \mathrm{kPa}$ stress. However, at 100\% RH the GCLs could be hydrated but would require a much longer time ( $>1$ year) to reach equilibrium. Therefore, the GCL should be in good contact with enough wet subsoil in field applications to hydrate properly and in a timely manner and in order to fulfil their primary purpose which is to minimise contaminant migration.

\section{ACKNOWLEDGEMENTS}

This study was supported under the Australian Research Council's Discovery funding scheme (project number ARC DP110104078). The authors offer their sincere appreciation to the council. The anonymous reviewers made many constructive comments and valuable suggestions. These comments and efforts associated with the review are greatly appreciated by the authors.

\section{NOTATION}

Basic SI units are given in parentheses.

$M \quad$ the molecular mass of water vapour $(18.016 \mathrm{~kg} / \mathrm{kmol})$

$M_{\text {bent }} \quad$ mass per unit area of bentonite $\left(\mathrm{kg} / \mathrm{m}^{3}\right)$

$M_{\mathrm{GCL}} \quad$ mass per unit area of GCL $\left(\mathrm{kg} / \mathrm{m}^{3}\right)$

$M_{\text {geo }}$ mass per unit area of geotextiles $\left(\mathrm{kg} / \mathrm{m}^{3}\right)$

$P_{\mathrm{e}}$ equilibrium vapour pressure of water $\left(\mathrm{N} / \mathrm{m}^{2}\right)$

$P_{0} \quad$ vapour pressure of water in air $\left(\mathrm{N} / \mathrm{m}^{2}\right)$

$R$ the universal gas constant $(8.31432 \mathrm{~J} / \mathrm{mol} / \mathrm{K})$

$\mathrm{RH}$ relative humidity in containers/desiccators (dimensionless)

$r_{2}$ mass of solute per $0.1 \mathrm{~kg}$ of water $(\mathrm{kg})$

$T$ absolute temperature (K)

$v$ the specific volume of water $\left(\mathrm{m}^{3} / \mathrm{kg}\right)$

$w_{2}$ solubility (dimensionless)

$\psi_{\mathrm{t}}$ total suction $\left(\mathrm{N} / \mathrm{m}^{2}\right)$

\section{REFERENCES}

Abuel-Naga, H. \& Bouazza, A. (2010). A novel laboratory technique to determine the water retention curve of geosynthetic clay liners. Geosynthetics International, 17, No. 5, 313-322.

Abuel-Naga, H. M. \& Bouazza, A. (2013). Thermo-mechanical behaviour of geosynthetic clay liners. Journal of Geotechnical and Geoenvironmental Engineering, 139, No. 4, 539-547. 
Abuel-Naga, H. M., Bouazza, A. \& Gates, W. P. (2013). Impact of bentonite form on the thermal evolution of the hydraulic conductivity of geosynthetic clay liners. Geotechnique Letters, 3, No. 2, 26-30.

Akin, I. D. \& Likos, W. J. (2014). Specific surface area of clay using water vapor and EGME sorption methods. Geotechnical Testing Journal, 37, No. 6, 1-12.

Anderson, R., Rayhani, M. T. \& Rowe, R. K. (2012). Laboratory investigation of GCL hydration from clayey sand subsoil. Geotextiles and Geomembranes, 31, 31-38.

ASTM D4318 Standard Test Method for Liquid Limit, Plastic Limit, and Plasticity Index of Soils. ASTM International, West Conshohocken, PA, USA.

ASTM D5890 Standard Test Method for Swell Index of Clay Mineral Component of Geosynthetic Clay Liners. ASTM International, West Conshohocken, PA, USA.

ASTM D6496 Standard Test Method for Determining Average Bonding Peel Strength between the Top and Bottom Layers of Needle-Punched Geosynthetic Clay Liners. ASTM International, West Conshohocken, PA, USA.

ASTM D7348 Standard Test Methods for Loss on Ignition (LOI) of Solid Combustion Residues. ASTM International, West Conshohocken, PA, USA.

ASTM E104 Standard Practice for Maintaining Constant Relative Humidity by Means of Aqueous Solutions. ASTM International, West Conshohocken, PA, USA.

Bannour, H., Stoltz, G., Delage, P. \& Touze-Foltz, N. (2014). Effect of stress on water retention of needlepunched geosynthetic clay liners. Geotextiles and Geomembranes, 42, No. 6, 629-640.

Beddoe, R. A., Take, W. A. \& Rowe, R. K. (2011). Water-retention behavior of geosynthetic clay liners. Journal of Geotechnical and Geoenvironmental Engineering, 137, No. 11, 1028-1038.

Bouazza, A. (2002). Geosynthetic clay liners. Geotextiles and Geomembranes, 20, No. 1, 3-17.

Bouazza, A. \& Gates, W. P. (2014). Overview of performance compatibility issues of GCLs with respect to leachates of extreme chemistry. Geosynthetics International, 21, No. 2, 151-167.

Bouazza, A. \& Rahman, F. (2007). Oxygen diffusion through partially hydrated geosynthetic clay liners. Geotechnique, 57, No. 9, 767-772.

Bouazza, A., Nahlawi, H. \& Alyward, M. (2011). In-situ temperature monitoring in an organic waste landfill cell. Journal of Geotechnical and Geoenvironmental Engineering, 137, No. 12, 1286-1289.

Bouazza, A., Zornberg, J., McCartney, J. \& Singh, R. M. (2013). Unsaturated geotechnics applied to geoenvironmental engineering problems involving geosynthetics. Engineering Geology, 165, $143-153$.

Bouazza, A., Singh, R. M., Rowe, R. K. \& Gassner, F. (2014). Heat and moisture migration in a geomembrane-GCL composite liner subjected to high temperatures and low vertical stresses. Geotextiles and Geomembranes, 42, No. 5, 555-563.

Bradshaw, S., Benson, C. H. \& Scalia, J. (2013). Hydration and cation exchange during subgrade hydration and effect on hydraulic conductivity of geosynthetic clay liners. Journal of Geotechnical and Geoenvironmental Engineering, 139, No. 4, 526-538.

Cases, J. M., Berend, I., Francois, M., Uriot, J. P., Michot, L. J. \& Thomas, T. (1997). Mechanism of adsorption and desorption of water vapour by homoionic montmorillonite: 3 . The $\mathrm{Mg} 2+$, $\mathrm{Ca} 2+, \mathrm{Sr} 2+$ and $\mathrm{Ba} 2+$ exchanged forms. Clays and Clay Minerals, 45, No. $1,8-22$

Chen, Y., Wang, Y. \& Xie, H. (2015). Breakthrough time-based design of landfill composite liners. Geotextiles and Geomembranes, 43, No. 2, 196-206.

Chevrier, B., Cazaux, D., Didier, G., Gamet, M. \& Guyonnet, D. (2012). Influence of subgrade, temperature and confining pressure on GCL hydration. Geotextiles and Geomembranes, 33, $1-6$.

Chiou, C. T. \& Rutherford, D. W. (1997). Effects of exchanged cation and layer charge on the sorption of water and EGME vapors on Montmorillonite clays. Clays and Clay Minerals, 45, No. 6, 867-880.
Clausen, P., Signorelli, M., Schreiber, A., Hughes, E., Plummer, C. J. G., Fessas, D., Schiraldi, A. \& Manson, J. E. (2009). Equilibrium desorption isotherms of water, ethanol, ethyl acetate, and toluene on a sodium smectite clay. Journal of Thermal Analysis and Calorimetry, 98, No. 3, 833-841.

Delage, P., Howat, M. D. \& Cui, Y. J. (1998). The relationship between suction and swelling properties in a heavily compacted unsaturated clay. Engineering Geology, 50, No. 1, 31-48.

Gates, W. P. \& Bouazza, A. (2010). Bentonite transformations in strongly alkaline solutions. Geotextiles and Geomembranes, 28, No. 2, 219-225.

Hornsey, W. P., Scheirs, J., Gates, W. P. \& Bouazza, A. (2010). The impact of mining solutions/liquors on geosynthetics. Geotextiles and Geomembranes, 28, No. 2, 191-198.

Johannesson, B. \& Janz, M. (2002). Test of four different experimental methods to determine sorption isotherms. Journal of Materials in Civil Engineering, 14, No. 6, 471-477.

Katsumi, T., Ishimori, H., Onikata, M. \& Fukagawa, R. (2008). Long-term barrier performance of modified bentonite materials against sodium and calcium permeant solutions. Geotextiles and Geomembranes, 26, No. 1, 14-30.

Kraehenbuehl, F., Stoeckli, H. F., Brunner, F., Kahr, G. \& Mueller-Vonmoos, M. (1987). Study of the water-bentonite system by vapour adsorption, immersion calorimetry and X-ray techniques: 1. Micropore volumes and internal surface areas, following Dubinin's theory. Clay Minerals, 22, No. 1, 1-9.

Kröhn, P. (2005). New evidence for the dominance of vapour diffusion during the re-saturation of compacted bentonite. Engineering Geology, 82, No. 2, 127-132.

Lee, J. M. \& Shackelford, C. D. (2005). Concentration dependency of the prehydration effect for a geosynthetic clay liner. Soils and Foundations, 45, No. 4, 27-41.

Lide, D. R. (2009). CRC Handbook of Chemistry and Physics, 89th edn (internet version), CRC Press/Taylor \& Francis, Boca Raton, FL, USA.

Likos, W. J. \& Lu, N. (2002). Water vapour sorption behaviour of smectite-kaolinite mixtures. Clays and Clay Minerals, 50, No. 5, $553-561$.

Likos, W. J. \& Lu, N. (2006). Pore scale analysis of bulk volume change from crystalline interlayer swelling in $\mathrm{Na}+-$ and $\mathrm{Ca} 2+-$ smectite. Clays and Clay Minerals, 54, No. 4, 515-528.

Liu, Y., Gates, W. P., Bouazza, A. \& Rowe, R. K. (2014). Fluid loss as a quick method to evaluate the hydraulic conductivity of geosynthetic clay liners under acidic conditions. Canadian Geotechnical Journal, 51, No. 2, 158-163.

Liu, Y., Bouazza, A., Gates, W. P. \& Rowe, R. K. (2015). Hydraulic performance of geosynthetic clay liners to sulfuric acid solutions. Geotextiles and Geomembranes, 43, No. 1, 14-23.

Makusa, G. P., Bradshaw, S. L., Berns, E., Benson, C. H. \& Knutsson, S. (2014). Freeze-thaw cycling concurrent with cation exchange and the hydraulic conductivity of geosynthetic clay liners. Canadian Geotechnical Journal, 51, No. 6, 591-598.

Mooney, R. W., Keenan, A. G. \& Wood, L. A. (1952). Adsorption of water vapor by montmorillonite. II. Effect of exchangeable ions and lattice swelling as measured by X-ray diffraction. Journal of American Chemical Society, 74, No. 6, 1371-1374.

Nahlawi, H., Bouazza, A. \& Kodikara, J. (2007). Characterisation of geotextiles water retention using a modified capillary pressure cell. Geotextiles and Geomembranes, 25, No. 3, 186-193.

Pintado, X., Lloret, E. \& Romero, E. (2009). Assessment of the use of vapour equilibrium technique in controlled-suction tests. Canadian Geotechnical Journal, 46, No. 4, 411-423.

Puma, S., Dominijanni, A., Manassero, M. \& Zaninetta, L. (2015). The role of physical pretreatments on the hydraulic conductivity of natural sodium bentonites. Geotextiles and Geomembranes, $\mathbf{4 3}$, No. 3, 263-271.

Rayhani, M. T., Rowe, R. K., Brachman, R. W. I., Take, W. A. \& Siemens, G. (2011). Factors affecting GCL hydration under isothermal conditions. Geotextiles and Geomembranes, 29, No. 6, $525-533$. 
Rockland, L. B. (1960). Saturated salt solutions for static control of relative humidity between $5^{\circ}$ and $40^{\circ} \mathrm{C}$. Analytical Chemistry, 32, No. $10,1375-1376$

Rouf, M. A., Singh, R. M., Bouazza, A. \& Rowe, R. K. (2013). Geosynthetic clay liner gas permeability relationship with moisture content and suction under pre-conditioning stresses. In Coupled Phenomena in Environmental Geotechnics, Manassero, M., Dominijanni, A., Foti, S. \& Musso, G., Editors, CRC Press, Rotterdam, the Netherlands, pp. 435-441.

Rouf, M. A., Singh, R. M., Bouazza, A., Rowe, R. K. \& Gates, W. P. (2014a). Gas permeability of partially hydrated geosynthetic clay liner under two stress conditions. Environmental Geotechnics, http:// dx.doi.org/10.1680/envgeo.14.00009.

Rouf, M. A., Singh, R. M., Bouazza, A., Gates, W. P. \& Rowe, R. K. (2014b). Sequential measurement of gas diffusion and gas permeability of a geosynthetic clay liner. Proceedings of the 7 th International Congress on Environmental Geotechnics, Melbourne, Australia, 11-14 November, pp. 722-729.

Rowe, R. K. (2005). Long-term performance of contaminant barrier systems, 45th Rankine Lecture. Geotechnique, 55, No. 9, 631-678.

Rowe, R. K. (2007). Advances and remaining challenges for geosynthetics in geoenvironmental engineering applications, 23rd Manual Rocha lecture. Soils and Rocks, 30, No. 1, 3-30.

Rowe, R. K. (2012). Short and long-term leakage through composite liners. Canadian Geotechnical Journal, 49, No. 2, 141-169.

Rowe, R. K. (2014) Performance of GCLs in liners for landfill and mining applications. Environmental Geotechnics, 1, No. 1, 3-21.

Rowe, R. K. \& Verge, A. E. (2013). Prediction of geosynthetic clay liner desiccation in low stress applications. Geosynthetics International, 20, No. 5, 301-315.

Rowe, R. K., Rayhani, M. T., Take, W. A., Siemens, G. \& Brachman, R. W. I. (2011). GCL hydration under simulated daily thermal cycles. Geosynthetics International, 18, No. 4, 196-205.
Rowe, R. K., Brachman, R. W. I., Take, W. A., Ashe, L. E. \& Rentz, A. (2014). Field and laboratory observations of down-slope bentonite migration in exposed composite liners. Proceedings of the 7 th International Congress on Environmental Geotechnics, Melbourne, Australia, 11-14 November, pp. 63-80.

Sumner, M. E. \& Miller, W. P. (1996). Cation exchange capacity and exchange coefficients. In Methods of soil analysis, Part 3, Chemical methods, Sparks, D. L., Editor, Book Series No. 5, Soil Science Society of America, Madison, WI, USA, pp. 1201-1229.

Tang, A. M. \& Cui, Y. J. (2005). Controlling suction by the vapour equilibrium technique at different temperatures and its application in determining the water retention properties of MX80 clay. Canadian Geotechnical Journal, 42, No. 1, 287-296.

Tang, A. M. \& Cui, Y. J. (2006). Use of saturated saline solution in determining the water retention curve of compacted bentonite at different temperatures. In Unsaturated Soils 2006, Miller, G. A., Zapata, C. E., Houston, S. L. \& Fredlund, D. G., Editors, Geotechnical Special Publication No. 147, American Society of Civil Engineers, Reston, VA, USA, pp. 1439-1450.

Vangpaisal, T. \& Bouazza, A. (2004). Gas permeability of partially hydrated geosynthetic clay liners. Journal of Geotechnical and Geoenvironmental Engineering, 130, No. 1, 93-102.

Vasko, S. M., Jo, H. Y., Benson, C. H., Edil, T. B. \& Katsumi, T. (2001). Hydraulic conductivity of partially prehydrated geosynthetic clay liners permeated with aqueous calcium chloride solutions. In Proceedings of Geosynthetics '01, Industrial Fabrics Association International (IFAI), Saint Paul, MN, USA, pp. 689-699.

Wexler, A. \& Hasegawa, S. (1954). Relative humidity temperature relationships of some saturated salt solutions in the temperature range $5^{\circ} \mathrm{C}$ to $50^{\circ} \mathrm{C}$. Journal of Research of National Bureau of Standards, 53, No. 1, 19-25.

The Editor welcomes discussion on all papers published in Geosynthetics International. Please email your contribution to discussion@geosynthetics-international.com by 15 October 2016. 